\title{
Pemanfaatan Alat Pengusangan Cepat Menggunakan Etanol untuk Pendugaan Vigor Daya Simpan Benih Jagung (Zea mays L.)
}

\section{The Use of Accelerated Aging Machine Using Ethanol to Estimate Corn (ea $\underline{\text { mays }}$ L.) Seed Vigor in Relation to Storability}

\author{
Zulfa Fauziyyah Taini, M. Rahmad Suhartanto*, dan Ahmad Zamzami \\ Departemen Agronomi dan Hortikultura, Fakultas Pertanian, Institut Pertanian Bogor \\ (Bogor Agricultural University), J1. Meranti, Kampus IPB Darmaga, Bogor 16680, Indonesia \\ Telp.\& Faks. 62-251-8629353 e-mail agrohort@ apps.ipb.ac.id \\ *Penulis Korespondensi: tantosuhartanto63@gmail.com
}

Disetujui : 08 November 2018 / Published Online 06 Mei 2019

\begin{abstract}
Accelerated aging method is a seed vigor testing after obtaining physical or chemical treatment that can provide simulated suboptimal environments that can mimicked the natural deterioration. This research using $96 \%$ ethanol vapor on seed (Zea mays L.) a accelerated aging machine IPB 77-1 MM to accelerate the deterioration of the seed. Utilization of these machines are intended to be seen accelerated aging of seeds and represent the natural deterioration of storage by controlled storage methods. This research used five lots of seed that classified by the vigor level from controlled deterioration by using $40{ }^{\circ} \mathrm{C}$ temperature and $98 \%$ relative humidity. The result of vigor classification from high to low is: P1 (94.5\% normal seedly), P2 (92.5\% normal seedly), P3 (70\% normal seedly), P4 (38\% normal seedly), and P5 (17\% normal seedly). The research consisted of two experiments, the first experiment is chemical accelerated aging that consist of five periods namely 0, 25 (1x25'), 50 (2x25'), 75 (3x25'), dan 100 (4x25) minutes. The second experiment is controlled storage in room temperature $\left(30-34{ }^{\circ} \mathrm{C}\right)$ and high relative humidity condition (85-99\%) by using saturated salt solution of $\mathrm{Na}_{2} \mathrm{SO}_{4}$. The storage is consist of five periods namely 0, 10, 20, 25, dan 30 days. This research aims to obtain the procedures for using APC IPB 77-1 MM in estimating the vigor related of corn seed by use chemical accelerated aging method. The result of the experiment showed that APC IPB 77-1 MM can be used to estimate the decrease in vigor of corn seeds. The result of the experiment also showed that APC IPB 77-1 MM can estimate vigor storability between natural storage with accelerated aging using ethanol vapor to all the seed lots on Seeds Germination and Maximum Growth Potential, meanwhile for the Vigor Index and Speed Growth is not sensitive to show consistency of the vigor decrease.
\end{abstract}

Keywords: APC IPB 77-1 MM, chemical accelerated aging method, controlled storage, corn

ABSTRAK

Pengusangan cepat adalah pengujian vigor daya simpan benih setelah mendapatkan pengusangan fisik maupun kimia yang dapat memberikan simulasi lingkungan suboptimum yang dapat menyebabkan kemunduran benih mirip seperti kondisi sebenarnya. Penelitian ini menggunakan metode pengusangan cepat kimia pada benih jagung dengan memanfaatkan alat pengusangan cepat tipe IPB 77-1 MM. Alat pengusangan cepat (APC IPB 77-1 MM) diharapkan merupakan mesin yang akan dapat mempercepat kemunduran benih dengan memanfaat uap etanol 96\%. Fungsi dari alat pengusangan cepat IPB 77-1 MM dimaksudkan agar dapat melihat kemunduran benih secara cepat yang bisa menggambarkan kemunduran mutu yang terjadi pada penyimpanan alami yang dalam penelitian ini ditunjukkan dengan menggunakan metode penyimpanan terkontrol. Penelitian ini menggunakan lima lot benih jagung dengan tingkat vigor yang berbeda hasil dari deteriorasi terkontrol pada suhu $40{ }^{\circ} \mathrm{C}$ dan RH 98\%. Hasil dari pembuatan lot benih dari vigor tinggi hingga rendah: P1 (94.5\% berkecambah normal), P2 (92.5\% berkecambah normal), P3 (70\% berkecambah normal), P4 (38\% berkecambah normal), dan P5 (17\% berkecambah normal). Penelitian ini terdiri dari dua percobaan, percobaan pertama adalah pengusangan cepat kimia yang terdiri atas 5 taraf waktu pengusangan yaitu $0,25\left(1 \times 25^{\prime}\right), 50\left(2 \times 25^{\prime}\right), 75\left(3 \times 25^{\prime}\right)$, dan 100 (4x25') menit. Percobaan kedua adalah penyimpanan terkontrol pada kondisi suhu kamar $\left(30-34{ }^{\circ} \mathrm{C}\right)$ dan $\mathrm{RH}$ tinggi (85-99\%) yang didapatkan dari larutan garam jenuh $\mathrm{Na}_{2} \mathrm{SO}_{4}$ dan terdiri dari 5 taraf waktu penyimpanan yaitu $0,10,20,25$, dan 30 hari.. Penelitian ini bertujuan untuk menguji pemanfaatan APC IPB 77-1 MM untuk pendugaan vigor daya simpan benih jagung dengan menggunakan pengusangan kimia. Hasil percobaan menunjukkan alat pengusangan cepat IPB 77-1 MM dapat digunakan untuk menduga penurunan vigor pada benih jagung. Hasil percobaan juga menunjukkan alat pengusangan cepat IPB 77-1 MM dapat menduga nilai vigor daya simpan yang sama dengan percobaan penyimpanan pada tolok ukur daya berkecambah dan potensi tumbuh maksimum sedangkan untuk tolok ukur indeks vigor dan kecepatan tumbuh belum menunjukkan konsistensi penurunan vigor.

Kata kunci: APC IPB 77-1 MM, jagung, pengusangan cepat kimia, penyimpanan terkontrol 


\section{PENDAHULUAN}

Jagung merupakan salah satu tanaman pangan penghasil sumber karbohidrat yang mempunyai peranan strategis dalam pertanian dan telah banyak dikonsumsi oleh masyarakat Indonesia. Jagung memiliki fungsi multiguna selain sebagai sumber pangan, jagung juga dimanfaatkan sebagai bahan baku industri serta pakan ternak yang membutuhkan jumlah yang besar. Luas lahan produksi tanaman jagung di Indonesia pada tahun 2014 adalah sebesar 3837 019 hektar dengan total produksi 19008426 ton (DitjenTP, 2016). Penyediaan benih jagung yang tinggi merupakan hal yang harus dilakukan untuk mencukupi kebutuhan tersebut. Kebutuhan benih jagung yang tinggi harus diimbangi dengan mutu benih yang tinggi untuk dapat mencapai hasil panen yang optimal.

Masalah yang dihadapi dalam usaha penyediaan benih bermutu tinggi adalah penyimpanan benih. Benih yang disimpan mengalami kemunduran mutu benih yang ditandai dengan turunnya kualitas, sifat atau viabilitas yang mengakibatkan rendahnya vigor benih dan jeleknya pertanaman serta menurunnya hasil. Cepatnya kemunduran mutu benih selama penyimpanan merupakan salah satu faktor pembatas produksi jagung di daerah tropis sehingga dapat mengurangi penyediaan benih berkualitas tinggi (Suhartanto, 2013). Kemunduran benih merupakan salah satu kendala dalam penyimpanan suatu benih. Hal ini dikarenakan proses kemunduran benih bersifat irreversible (tidak dapat dibalikkan), inexorable (tidak dapat dihentikan) dan inevitable (tidak dapat dihindari) (Tatipata, 2004). Daya simpan benih dipengaruhi oleh faktor lingkungan dan faktor genetik. Penyimpanan benih yang relatif lama akan berpengaruh terhadap turunnya daya tumbuh benih. Benih yang memiliki vigor tinggi akan mampu menjaga daya tumbuhnya hingga waktu tertentu selama di penyimpanan.

Menurut Suhartanto (2013) vigor daya simpan merupakan suatu parameter vigor benih yang menunjukkan kemampuan benih untuk disimpan dalam keadan suboptimum. Benih yang memiliki vigor daya simpan tinggi mampu disimpan untuk periode simpan yang normal dalam keadaan suboptimum dan akan lebih panjang daya simpannya jika dalam keadaan ruang simpan yang optimum. Vigor daya simpan benih dapat dideteksi dengan metode pengusangan cepat benih. Dugaan viabilitas benih setelah disimpan dapat dilakukan dengan proses pengusangan dalam waktu yang jauh lebih singkat. Menurut Mugnisjah et al. (1994) teknik pengusangan cepat adalah pengujian vigor daya simpan benih setelah mendapatkan pengusangan fisik yang dapat memberikan simulasi lingkungan suboptimum yang dapat menyebabkan kemunduran benih mirip seperti kondisi sebenarnya.

Menurut Sadjad (1993) pada tahun 1964, Sadjad menemukan secara intuitif bahwa cairan etanol dapat memundurkan benih jagung, sehingga dikembangkan metode pengusangan cepat menggunakan senyawa kimiawi yaitu dengan etanol. Berdasarkan penelitian tersebut Sadjad menciptakan alat pengusangan cepat IPB 77-1. Alat tersebut terus mengalami modifikasi lanjut untuk mencapai efisiensi lebih tinggi dari sebelumnya. Hasil modifikasi alat pengusangan cepat tersebut ialah Alat Pengusangan Cepat (APC) tipe IPB 77-1 MM. Badriah (2012) Alat pengusangan cepat IPB 77-1 MM ini dirancang untuk memungkinkan terjadinya devigorasi benih secara bertahap agar proses devigorasi tersebut hanya terfokus pada benih yang akan didera. Penelitian mengenai pendugaan vigor daya simpan pada benih jagung dengan metode pengusangan cepat kimia menggunakan alat pengusangan cepat IPB 77-1 MM diharapkan dapat menggambarkan proses kemunduruan benih dengan waktu yang relatif singkat dan akurat. Penelitian Terryana (2015) menyebutkan kelebihan dari pengusangan cepat benih secara kimia menggunakan alat pengusangan cepat IPB 77-1 MM memerlukan waktu relatif lebih singkat dalam menurunkan daya perkecambahan benih. Selain itu, dari segi teknis, metode pengusangan cepat benih secara kimia relatif lebih mudah dan lebih cepat dalam prosedur pengoperasiannya. Penelitian ini bertujuan untuk menguji pemanfaatan APC IPB 77-1 MM untuk menduga vigor daya simpan benih jagung dengan menggunakan etanol.

\section{BAHAN DAN METODE}

Penelitian dilaksanakan mulai bulan Januari 2018 hingga April 2018 di Laboratorium Ilmu dan Teknologi Benih, Departemen Agronomi dan Hortikultura, Fakultas Pertanian, Institut Pertanian Bogor. Bahan yang digunakan dalam percobaan ini adalah benih jagung varietas Bisma, plastik, kertas buram, larutan garam jenuh $\mathrm{Na}_{2} \mathrm{SO}_{4}$, fungisida, label, akuades, dan etanol 96\%. Alat yang digunakan adalah Alat Pengusangan Cepat tipe IPB 77-1 MM, alat pengepres kertas tipe IPB $75-1$, oven, germinator tipe IPB 72-1, termohigrometer, desikator, cawan, gelas piala, saringan, labu semprot, toples dan timbangan. 


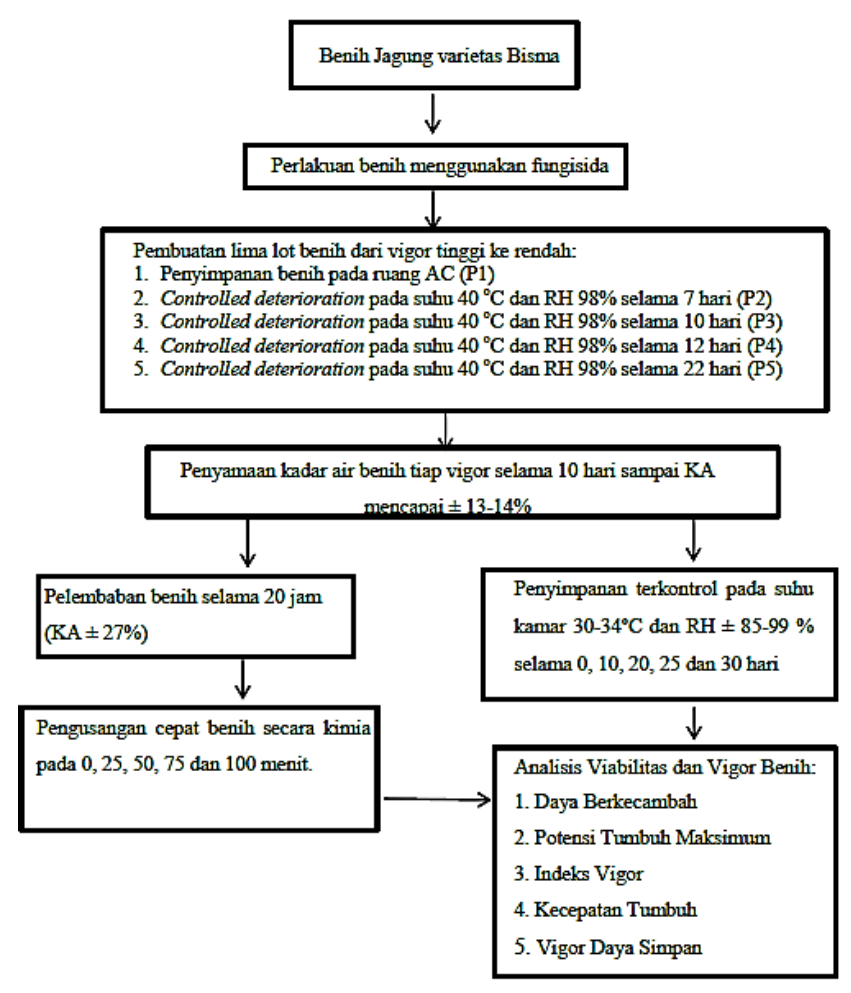

Gambar 1. Diagram alir pelaksanaan penelitian

Penelitian ini terdiri dari dua percobaan. Percobaan I adalah pengusangan cepat secara kimia dengan menggunakan Alat Pengusangan Cepat IPB 77-1 MM. Percobaan II adalah penyimpanan terkontrol benih dengan menggunakan larutan garam jenuh $\mathrm{Na}_{2} \mathrm{SO}_{4}$. Rancangan percobaan yang digunakan dalam penelitian adalah Rancangan Kelompok Lengkap Teracak (RKLT) dengan satu faktor, yaitu lama waktu penyimpanan dan lama waktu pengusangan. Pengusangan cepat yang digunakan dalam penelitian ini adalah metode pengusangan cepat secara kimia menggunakan APC IPB 77-1 MM. Benih diusangkan dengan uap etanol $96 \%$ dengan waktu pengusangan yaitu $0,25,50,75$, dan 100 menit. Suhu dan kelembaban yang tercipta dalam ruang deraan adalah $\pm 31^{\circ} \mathrm{C}$ dan \pm $82 \%$. Penyimpanan terkontrol dilakukan dengan menggunakan toples yang berisi larutan garam $\mathrm{Na} 2 \mathrm{SO} 4$ jenuh dalam suhu kamar $30-34^{\circ} \mathrm{C}$ dan RH $85-99 \%$. Setiap lot benih ditimbang sebanyak \pm 50 gram per perlakuan. Penyimpanan dilakukan dengan waktu $0,10,20,25$, dan 30 hari sebanyak empat ulangan. Sebelum dilakukan penyimpanan benih terlebih dahulu diberikan perlakuan fungisida untuk mengindari adanya kontaminasi cendawan.

Pelaksanaan kegiatan penelitian diawali dengan pembuatan lot benih mengacu pada penelitian Badriah (2012), pembuatan lot benih bertujuan untuk memperoleh benih dengan tingkat vigor yang berbeda. Lot benih tersebut terdiri dari penyimpanan benih pada ruang $\mathrm{AC}(\mathrm{P} 1)$ dan controlled deterioration pada suhu $40{ }^{\circ} \mathrm{C}$ dan kelembaban 98\% selama 7 hari (P2), controlled deterioration pada suhu $40{ }^{\circ} \mathrm{C}$ dan kelembaban 98\% selama 10 hari (P3), controlled deterioration pada suhu $40{ }^{\circ} \mathrm{C}$ dan kelembaban $98 \%$ selama 12 hari (P4) dan controlled deterioration pada suhu $40{ }^{\circ} \mathrm{C}$ dan kelembaban $98 \%$ selama 22 hari (P5). Benih sebelumnya diberi perlakuan fungisida untuk menghindari kontaminasi cendawan saat proses controlled deterioration berlangsung. Controlled deterioration di dapatkan dengan menyimpan benih menggunakan toples yang di dalamnya berisi air sebanyak $800 \mathrm{ml}$. Lot benih diletakkan diatas saringan yang berada di dalam toples dan di masukkan dalam oven pada suhu 40 ${ }^{\circ} \mathrm{C}$ dan kelembaban tinggi $98 \%$. Benih kemudian dipaparkan pada suhu ruang dengan tujuan untuk mendapatkan kadar air kesetimbangan, sehingga benih memiliki kadar air yang seragam dan tidak menjadi faktor yang mempengaruhi dalam pengujian viabilitas serta vigor benih.

Pengusangan cepat secara kimia menggunakan APC IPB 77-1 MM mengacu pada penelitian Badriah (2012), yaitu lot benih yang telah didapatkan dari controlled deterioration dilembabkan terlebih dahulu sebelum dilakukan pengusangan menggunakan APC IPB 77-1 MM. Pengusangan cepat dengan APC IPB 77-1 MM dilakukan dengan uap etanol $96 \%$. Setiap melakukan percobaan, etanol harus selalu diganti dengan etanol yang baru sehingga sisa etanol pada APC IPB 77-1 MM harus dibuang. Benih hasil perlakuan tersebut selanjutnya dikecambahkan dengan metode Uji Kertas Digulung dalam Plastik (UKDdP) pada germinator tipe IPB 72-1 dan diamati viabilitasnya dengan tolok ukur kecepatan tumbuh, daya berkecambah, indeks vigor dan potensi tumbuh maksimum.

Pengamatan yang dilakukan meliputi tolok ukur viabilitas dan vigor benih yaitu daya berkecambah, indeks vigor, potensi tumbuh maksimum, kecepatan tumbuh dan vigor daya simpan benih. Pengukuran kadar air dilakukan dengan metode langsung menggunakan oven suhu tinggi konstan (130-133) selama (4 jam \pm 12 menit) (ISTA, 2014). Persentase daya berkecambah dihitung berdasarkan jumlah persentase kecambah normal pada pengamatan pertama yang dilakukan pada hari ke-4 dan pengamatan kedua pada hari ke-7. Kecepatan Tumbuh (KCT) adalah persentase kecambah normal per satuan waktu atau etmal. KCT dihitung atas dasar waktu yang digunakan untuk tumbuh. Indeks vigor adalah persentase kecambah normal pada hitungan pertama yaitu pada hari ke4. Potensi tumbuh maksimum merupakan tolak ukur parameter viabilitas total. Potensi tumbuh 
maksimum dihitung berdasarkan jumlah kecambah normal dan abnormal yang tumbuh sampai akhir periode pengujian (hari ke-7). Nilai vigor daya simpan diperoleh dari nisbah antara vigor awal (VA) dengan sudut kemiringan garis regresi linier $(\alpha)$, sudut kemiringan garis regresi $(\alpha)$ didapatkan berdasarkan hasil analisis persamaan regresi linier $(\mathrm{Y}=\mathrm{a}+\mathrm{bx})$ yang menggambarkan hubungan antara waktu pengusangan (sumbu $\mathrm{x}$ ) dan variabel viabilitas dan vigor benih (sumbu y) dengan menghitung tan-1 $\mathrm{b}$ terlebih dahulu.

\section{HASIL DAN PEMBAHASAN}

\section{Status Viabilitas dan Vigor Benih Jagung}

Analisis ragam dilakukan untuk mengetahui pengaruh waktu pengusangan terhadap tolok ukur yang diamati. Hasil rekapitulasi sidik ragam menunjukkan bahwa lama waktu pengusangan berpengaruh nyata pada taraf $1 \%$ terhadap semua tolok ukur viabilitas dan vigor benih (Tabel 1).

Tabel 1. Rekapitulasi sidik ragam pada tolok ukur viabilitas dan vigor benih

\begin{tabular}{lcr}
\hline \multicolumn{1}{c}{ Tolok Ukur } & $\begin{array}{c}\text { F Hitung } \\
\text { Ulangan }\end{array}$ & $\begin{array}{c}\text { F Hitung } \\
\text { Waktu } \\
\text { Pengusangan }\end{array}$ \\
\hline Daya Berkecambah & $0.21 \mathrm{tn}$ & $36.17^{* *}$ \\
Indeks vigor & $2.49 \mathrm{tn}$ & $14.53^{* *}$ \\
Potensi Tumbuh Maks & $0.50 \mathrm{tn}$ & $7.44^{* *}$ \\
Kecepatan Tumbuh & $0.05 \mathrm{tn}$ & $17.39^{* *}$ \\
\hline
\end{tabular}

Keterangan: **: berpengaruh nyata pada taraf $\alpha=1 \%$, tn: tidak berpengaruh nyata.

Hasil analisis menunjukkan bahwa pengelompokkan berdasarkan ulangan tidak berpengaruh nyata pada semua tolok ukur viabilitas dan vigor benih. Hasil analisis tersebut menunjukkan bahwa lingkungan bersifat homogen sehingga pengelompokkan tidak berpengaruh terhadap tolok ukur viabilitas dan vigor benih.

Parameter viabilitas dan vigor benih yang diamati terdiri dari Daya Berkecambah, Indeks Vigor, Potensi Tumbuh Maksimum dan Kecepatan
Tumbuh. Pengujian terhadap viabilitas dan vigor awal benih dilakukan pada lima lot benih jagung, yaitu P1, P2, P3, P4 dan P5 (Tabel 2).

Berdasarkan hasil uji lanjut Beda Nyata Jujur (BNJ) menunjukkan bahwa pada parameter daya berkecambah dari kelima lot benih yang diujikan terdapat lot benih dengan vigor awal tertinggi yaitu P1 dan P2, sehingga berdasarkan parameter daya berkecambah menunjukkan keberhasilan pada pembuatan lot yang ditunjukkan dengan perbedaan tingkat vigor yang dihasilkan pada P1, P3, P4 dan P5 sedangkan untuk P2 vigor awal menunjukkan hasil yang sama dengan P1. Hasil yang sama juga ditunjukkan dari parameter potensi tumbuh maksimum, berdasarkan parameter potensi tumbuh maksimum dari kelima lot benih, empat diantaranya memiliki perbedaan tingkat vigor yang dihasilkan dari pembuatan lot yaitu pada P1, P3, P4 dan P5. Sedangkan pada parameter indeks vigor dan kecepatan tumbuh benih hasil dari pembuatan lot hanya menghasilkan tiga tingkat vigor yang berbeda. Dari keempat parameter yang diujikan, pembuatan lot benih dengan membuat perbedaan tingkat vigor dinilai telah berhasil untuk dilakukan.

\section{Viabilitas dan Vigor Benih Jagung pada Penyimpanan Terkontrol dan Pengusangan}

Hasil pengujian menunjukkan adanya penurunan hasil yang sejalan dengan lamanya waktu penyimpanan dan lamanya waktu pengusangan pada semua tolok ukur viabilitas dan vigor benih yaitu pada daya berkecambah, indeks vigor, potensi tumbuh maksimum dan kecepatan tumbuh. Pada semua tolok ukur, penurunan viabilitas benih hasil penyimpanan maupun pengusangan terjadi secara gradual. Penyimpanan dengan tolok ukur DB, IV, KCT pada P4 dan P5 menyebabkan benih kehilangan viabilitas namun dengan metode pengusangan benih yang dihasilkan masih memiliki viabilitas kecuali pada tolok ukur indeks vigor (Tabel 3).

Tabel 2. Rata-rata nilai tengah viabilitas dan vigor awal lima lot benih jagung

\begin{tabular}{ccccc}
\hline Tingkat Vigor & DB $(\%)$ & IV $(\%)$ & $\mathrm{K}_{\mathrm{CT}}\left(\% \mathrm{etmal}^{-1}\right)$ & $\mathrm{PTM}(\%)$ \\
\hline P1 & $94.50 \mathrm{a}$ & $9.50 \mathrm{a}$ & $19.54 \mathrm{a}$ & $98.50 \mathrm{a}$ \\
P2 & $92.50 \mathrm{a}$ & $5.00 \mathrm{~b}$ & $18.43 \mathrm{a}$ & $98.00 \mathrm{a}$ \\
P3 & $70.00 \mathrm{~b}$ & $1.50 \mathrm{c}$ & $13.72 \mathrm{~b}$ & $85.50 \mathrm{~b}$ \\
P4 & $38.00 \mathrm{c}$ & $0.00 \mathrm{c}$ & $6.10 \mathrm{c}$ & $61.50 \mathrm{c}$ \\
P5 & $17.00 \mathrm{~d}$ & $0.00 \mathrm{c}$ & $3.26 \mathrm{c}$ & $42.50 \mathrm{~d}$ \\
\hline
\end{tabular}

Keterangan: P1: Benih jagung disimpan pada suhu AC; P2: Controlled deterioration benih jagung selama 7 hari; P3: Controlled deterioration benih jagung selama 10 hari. P4: Controlled deterioration benih jagung selama 12 hari; P5: Controlled deterioration benih jagung selama 22 hari; DB: Daya Berkecambah; IV: Indeks Vigor; KCT: Kecepatan Tumbuh; PTM: Potensi Tumbuh Maksimum. Angka yang diikuti dengan huruf yang sama pada kolom, menunjukkan tidak berbeda nyata menurut Uji Tukey pada taraf $5 \%$. 
Tabel 3. Hasil pengujian viabilitas dan vigor benih selama penyimpanan dan pengusangan

\begin{tabular}{|c|c|c|c|c|c|c|c|c|c|c|}
\hline \multirow{2}{*}{ Lot Benih } & \multicolumn{5}{|c|}{ Penyimpanan Terkontrol } & \multicolumn{5}{|c|}{ Pengusangan Kimia } \\
\hline & 0 hari & 10 hari & 20 hari & 25 hari & 30 hari & 0 menit & 25 menit & 50 menit & 5 menit 1 & menit \\
\hline \multicolumn{11}{|c|}{ Daya Berkecambah (\%) } \\
\hline P1 & 94.5 & 92.5 & 82.50 & 73.5 & 64.5 & 94.5 & 95.0 & 89.0 & 66.0 & 6.5 \\
\hline $\mathrm{P} 2$ & 92.5 & 79.5 & 71.0 & 53.5 & 39.5 & 92.5 & 91.5 & 86.5 & 53.0 & 7.0 \\
\hline P3 & 70.0 & 54.5 & 39.0 & 24.0 & 14.0 & 70.0 & 71.0 & 72.0 & 40.0 & 7.5 \\
\hline P4 & 38.0 & 12.5 & 0.0 & 0.0 & 0.0 & 38.0 & 41.5 & 31.5 & 16.0 & 1.5 \\
\hline P5 & 17.0 & 4.0 & 0.5 & 0.0 & 0.0 & 17.0 & 21.5 & 17.0 & 11.5 & 8.0 \\
\hline \multicolumn{11}{|c|}{ Indeks Vigor $(\%)$} \\
\hline P1 & 9.5 & 28.5 & 11.0 & 6.0 & 4.0 & 9.5 & 50.5 & 33.5 & 15.0 & 1.0 \\
\hline $\mathrm{P} 2$ & 5.0 & 13.5 & 4.5 & 0.5 & 0.0 & 5.0 & 25.0 & 25.5 & 9.5 & 0.0 \\
\hline P3 & 1.5 & 2.0 & 0.0 & 0.0 & 0.0 & 1.5 & 12.5 & 9.5 & 3.0 & 0.0 \\
\hline P4 & 0.0 & 0.0 & 0.0 & 0.0 & 0.0 & 0.0 & 2.0 & 2.0 & 0.0 & 0.0 \\
\hline P5 & 0.0 & 0.0 & 0.0 & 0.0 & 0.0 & 0.0 & 0.5 & 0.0 & 0.5 & 0.0 \\
\hline \multicolumn{11}{|c|}{ Potensi Tumbuh Maksimum (\%) } \\
\hline $\mathrm{P} 1$ & 98.5 & 95.0 & 88.0 & 85.5 & 78.5 & 98.5 & 98.0 & 92.5 & 71.5 & 8.5 \\
\hline $\mathrm{P} 2$ & 98.0 & 84.0 & 81.0 & 68.5 & 59.0 & 98.0 & 96.5 & 91.0 & 61.0 & 8.0 \\
\hline P3 & 85.5 & 68.0 & 58.0 & 51.0 & 34.5 & 85.5 & 85.5 & 79.5 & 51.5 & 8.0 \\
\hline P4 & 61.5 & 33.5 & 5.5 & 3.0 & 0.0 & 61.5 & 61.5 & 47.0 & 24.5 & 2.5 \\
\hline P5 & 42.5 & 17.0 & 2.0 & 0.5 & 0.0 & 42.5 & 41.5 & 28.5 & 21.0 & 11.0 \\
\hline \multicolumn{11}{|c|}{ Kecepatan Tumbuh $\left(\%\right.$ etmal $\left.^{-1}\right)$} \\
\hline P1 & 19.5 & 19.9 & 16.3 & 15.3 & 13.0 & 19.5 & 22.6 & 19.2 & 13.9 & 0.6 \\
\hline $\mathrm{P} 2$ & 18.4 & 15.2 & 12.9 & 9.2 & 7.1 & 18.4 & 19.8 & 19.3 & 12.0 & 1.4 \\
\hline P3 & 13.7 & 9.6 & 5.8 & 4.3 & 1.8 & 13.7 & 14.2 & 13.6 & 7.6 & 1.8 \\
\hline $\mathrm{P} 4$ & 6.1 & 2.2 & 0.0 & 0.0 & 0.0 & 6.1 & 7.3 & 5.2 & 2.9 & 0.0 \\
\hline P5 & 3.2 & 0.6 & 0.0 & 0.0 & 0.0 & 3.2 & 3.8 & 3.0 & 1.8 & 0.9 \\
\hline
\end{tabular}

Daya berkecambah diamati dengan menghitung jumlah kecambah normal pada hari keempat dan hari ketujuh setelah pengecambahan. Hasil menunjukkan bahwa daya berkecambah kelima lot benih mengalami penurunan sejalan dengan lamanya waktu penyimpanan dan pengusangan, akan tetapi lot benih $\mathrm{P} 1$ dan $\mathrm{P} 2$ mempunyai vigor yang lebih tinggi dari lot benih lainnya, hal ini dapat dilihat dari kemampuan kedua lot benih tersebut mempertahankan daya berkecambahnya sampai akhir masa penyimpanan dan pengusangan, sedangkan daya berkecambah lot benih P3, P4, dan P5 menunjukkan penurunan daya berkecambah yang signifikan. Penelitian Radha et al. (2013) yang melakukan pengujian terhadap benih dengan menyimpannya pada suhu dan RH yang tinggi menghasilkan penurunan daya berkecambah seiring dengan lamanya waktu penyimpanan. Penurunan daya berkecambah benih selama penyimpanan diindikasikan karena kerusakan yang terjadi pada jaringan embrionik selama penyimpanan menyebabkan kematian pada benih yang cukup dapat mengganggu proses perkecambahan. Menurut Sheidaei et al. (2014) penurunan daya berkecambah secara signifikan juga disebabkan oleh semakin lamanya suatu periode penyimpanan yang dilakukan. Selain itu jumlah perkecambahan yang abnormal juga meningkat secara signifikan seiring dengan menurunnya daya berkecambah.

Indeks vigor diamati dengan menghitung jumlah kecambah normal pada hari keempat. Hasil pengujian menunjukkan lot benih P1 dan P2 mempunyai persentase yang lebih tinggi dari lot benih P3, P4, dan P5. Indeks vigor yang rendah pada P3 menunjukkan bahwa jumlah kecambah yang dihasilkan oleh lot benih P3 pada hari keempat masih banyak yang belum dapat dikategorikan sebagai kecambah normal, sedangkan pada lot benih P4 dan P5 tidak ada kecambah normal yang dihasilkan pada hari keempat dari kedua lot tersebut selama masa penyimpanan namun selama pengusangan kedua lot benih tersebut masih memiliki kecambah normal di hari keempat pengecambahan. Nurfarida (2011) menyatakan bahwa benih yang indeks vigornya tinggi berarti memiliki vigor kekuatan tumbuh yang tinggi karena tetap memiliki kemampuan untuk berkecambah secara normal pada hitungan pertama meskipun energi atau cadangan makanan digunakan untuk berespirasi.

Potensi tumbuh maksimum merupakan tolak ukur parameter viabilitas total. Potensi tumbuh maksimum dihitung berdasarkan jumlah kecambah normal dan abnormal yang tumbuh 
sampai akhir periode pengujian (hari ke-7). Rahmawati et al. (2016) mengemukakan bahwa tolok ukur potensi tumbuh maksimum menunjukkan benih yang tumbuh, baik menjadi kecambah normal maupun abnormal. Kelima lot benih mengalami penurunan potensi tumbuh maksimum sejalan dengan lamanya waktu penyimpanan dan pengusangan. Lot benih $\mathrm{P} 1$ memiliki nilai potensi tumbuh maksimum tertinggi, sedangkan P5 memiliki nilai potensi tumbuh maksimum terendah.

Kecepatan tumbuh (KCT) benih merupakan tolok ukur yang mengindikasikan vigor kekuatan tumbuh (VKT) dan merupakan tolok ukur yang lebih peka dibandingkan DB (Paramita et al., 2018). Persentase kecepatan tumbuh menunjukkan banyaknya jumlah tambahan perkecambahan setiap hari atau etmal selama kurun waktu pengamatan. Pengamatan dilakukan setiap hari setelah munculnya kecambah normal hari pertama pengamatan hingga akhir pengamatan. Lot benih P1 dan P2 mempunyai persentase kecepatan tumbuh yang lebih tinggi daripada lot benih lainnya. Hal tersebut dikarenakan lot benih P1 dan P2 merupakan lot benih yang lebih vigor dari benih lainnya. Menurut Widajati et al. (2012) yang menyatakan bahwa kecepatan tumbuh benih mencerminkan vigor individual benih dikaitkan dengan waktu.

\section{Hubungan Viabilitas dan Vigor Benih antara Penyimpanan Terkontrol dengan Pengusangan}

Berdasarkan hasil analisis regresi antara daya berkecambah, indeks vigor, potensi tumbuh maksimum dan kecepatan tumbuh benih selama penyimpanan dan pengusangan menunjukkan bahwa terdapat dua lot benih yang memiliki nilai koefisien korelasi (r) yang tinggi. Hal tersebut dikarenakan pada Tabel 4 tingkat vigor pada lot benih P1 dan P2 yang digunakan menunjukkan vigor awal yang tinggi (>80\%), sedangkan $\mathrm{P} 3, \mathrm{P} 4$, dan P5 mempunyai vigor awal yang rendah $(<80 \%)$. Menurut Badan Standardisasi Nasional (2003) salah satu standar kelulusan lot benih jagung adalah daya berkecambah minimal $80 \%$, sehingga jika daya berkecambah benih kurang dari standar tersebut tidak dapat dikatakan sebagai benih. Oleh karena itu, lot benih P3, P4, dan P5 tidak dapat dibandingkan dengan $\mathrm{P} 1$ dan $\mathrm{P} 2$, karena vigor awal yang dimiliki rendah. Nilai korelasi yang mendekati $1(\mathrm{r} \approx 1)$ menunjukkan keeratan hubungan antara viabilitas dan vigor benih selama penyimpanan dan selama pengusangan. Kesesuaian tolok ukur daya

Tabel 4. Hubungan daya berkecambah, indeks vigor, potensi tumbuh maksimum, dan kecepatan tumbuh antara penyimpanan terkontrol dengan pengusangan

\begin{tabular}{|c|c|c|c|}
\hline Hubungan Penyimpanan x Pengusangan & Persamaan Regresi & $\mathrm{R}^{2}$ & $\mathrm{r}$ \\
\hline & P1 & & \\
\hline DB penyimpanan $\mathrm{x}$ DB pengusangan & $y=60.00+0.30 x$ & 0.81 & $0.90 *$ \\
\hline IV penyimpanan x IV pengusangan & $y=2.16+0.44 x$ & 0.81 & $0.90 *$ \\
\hline PTM penyimpanan $x$ PTM pengusangan & $y=75.70+0.18 x$ & 0.77 & $0.87^{\mathrm{tn}}$ \\
\hline \multirow[t]{2}{*}{ KCT penyimpanan $\mathrm{x}$ KCT pengusangan } & $y=12.30+0.29 x$ & 0.80 & $0.88^{*}$ \\
\hline & P2 & & \\
\hline DB penyimpanan x DB pengusangan & $y=32.20+0.53 x$ & 0.86 & $0.93 *$ \\
\hline IV penyimpanan x IV pengusangan & $y=0.49+0.32 x$ & 0.49 & $0.70^{\text {tn }}$ \\
\hline PTM penyimpanan $x$ PTM pengusangan & $y=53.30+0.35 x$ & 0.80 & $0.89 *$ \\
\hline \multirow[t]{2}{*}{ KCT penyimpanan $\mathrm{x}$ KCT pengusangan } & $y=5.69+0.48 x$ & 0.69 & $0.83^{\text {tn }}$ \\
\hline & P3 & & \\
\hline DB penyimpanan $x$ DB pengusangan & $y=5.50+0.66 x$ & 0.70 & $0.83^{\text {tn }}$ \\
\hline IV penyimpanan x IV pengusangan & $y=0.30+0.07 x$ & 0.17 & $0.41^{\text {tn }}$ \\
\hline PTM penyimpanan $\mathrm{x}$ PTM pengusangan & $y=28.30+0.50 x$ & 0.77 & $0.88^{\text {th }}$ \\
\hline \multirow[t]{2}{*}{ KCT penyimpanan $\mathrm{X}$ KCT pengusangan } & $y=0.02+0.69 x$ & 0.63 & $0.79^{\text {tn }}$ \\
\hline & $\mathrm{P} 4$ & & \\
\hline DB penyimpanan $\mathrm{x}$ DB pengusangan & $y=-5.20+0.59 x$ & 0.36 & $0.60^{\mathrm{tn}}$ \\
\hline IV penyimpanan x IV pengusangan & $y=0$ & 1.00 & $1.00^{\text {tn }}$ \\
\hline PTM penyimpanan $x$ PTM pengusangan & $y=-10.90+0.80 x$ & 0.60 & $0.77^{\text {tn }}$ \\
\hline \multirow[t]{2}{*}{ KCT penyimpanan $\mathrm{x} \mathrm{KCT}$ pengusangan } & $y=-0.58+0.51 x$ & 0.32 & $0.56^{\mathrm{tn}}$ \\
\hline & P5 & & \\
\hline DB penyimpanan x DB pengusangan & $y=-3.90+0.54 x$ & 0.15 & $0.39^{\text {tn }}$ \\
\hline IV penyimpanan x IV pengusangan & $y=0$ & 1.00 & $1.00^{\mathrm{tn}}$ \\
\hline PTM penyimpanan $\mathrm{x}$ PTM pengusangan & $y=-18.90+1.08 x$ & 0.64 & $0.80^{\text {tn }}$ \\
\hline KCT penyimpanan $\mathrm{x}$ KCT pengusangan & $y=-0.64+0.55 x$ & 0.21 & $0.46^{\mathrm{tn}}$ \\
\hline
\end{tabular}

Keterangan: *: berpengaruh nyata pada taraf $\alpha=5 \%$, tn: tidak berpengaruh nyata. 
berkecambah, indeks vigor, potensi tumbuh maksimum, dan kecepatan tumbuh benih selama penyimpanan dan pengusangan dapat diketahui dengan melihat nilai korelasi yang nyata. Hal ini menunjukkan bahwa pengusangan cepat secara kimia menggunakan etanol dapat menyebabkan penurunan hasil yang sama dengan penyimpanan terkontrol pada semua tolok ukur viabilitas dan vigor benih kecuali pada tolok ukur potensi tumbuh maksimum pada lot benih P1 dan kecuali pada tolok ukur indeks vigor dan kecepatan tumbuh benih pada P2.

\section{Analisis Nilai Vigor Hasil Pengusangan Kimia dan Penyimpanan Terkontrol}

Menurut Badriah (2012) nilai vigor hasil pengusangan merupakan nilai dari hasil bagi vigor awal benih (Va) dengan besar sudut kemiringan garis $(\alpha)$. Nilai vigor daya simpan berbanding lurus dengan vigor awal dan berbanding terbalik dengan sudut kemiringan $(\alpha)$. Semakin besar $\mathrm{Va}$ dan semakin kecil $\alpha$ maka vigor daya simpan semakin besar. Hasil analisis menunjukkan kemiringan garis pada pengusangan kimia berkisar $0.45-40^{\circ}$ sedangkan pada pengusangan terkontrol kemiringan garis yang terbentuk adalah $3-64^{\circ}$. Nilai vigor yang diperoleh diharapkan dapat digunakan untuk menganalisis vigor daya simpan benih jagung yang dilihat dari laju penurunan garis regresinya.

Hasil analisis nilai vigor yang dihasilkan menunjukkan pengusangan cepat secara kimia menggunakan Alat Pengusangan Cepat tipe IPB 77-1 MM dapat digunakan untuk melihat perbedaan vigor daya simpan benih pada parameter daya berkecambah dan potensi tumbuh maksimum. Hasil pengujian menunjukkan bahwa vigor daya simpan secara alami melalui penyimpanan terkontrol diduga sama dengan vigor daya simpan buatan melalui pengusangan kimia menggunakan etanol, kecuali pada P5 pada tolok ukur daya berkecambah pada vigor daya simpan buatan (Tabel 5). Sedangkan untuk tolok ukur indeks vigor dan kecepatan tumbuh benih, pengusangan cepat secara kimia menggunakan Alat Pengusangan Cepat tipe IPB 77-1 MM dinilai kurang sensitif untuk melihat perbedaan vigor daya simpan. Menurut Zanzibar dan Pramono (2009) menyatakan bahwa perlakuan penderaan merupakan fungsi waktu; makin tinggi daya tahan benih terhadap perlakuan penderaan, diasumsikan benih tersebut memiliki daya simpan relatif tinggi serta dalam penyimpanannya tidak memerlukan perlakuan khusus.

Nilai vigor daya simpan yang tinggi menunjukkan bahwa benih tersebut memiliki daya simpan yang lama. Hasil pengujian menghasilkan
Tabel 5. Nilai vigor hasil pengusangan kimia dan penyimpanan terkontrol

\begin{tabular}{cccc}
\hline Lot Benih & \multicolumn{2}{c}{ V $_{\text {DS-alami }}$ Lot Benih } & V $_{\text {DS-alami }}$ \\
\hline \multicolumn{4}{c}{ Daya } \\
P1 & 2.10 & P5 & $\mathbf{2 . 6 6}$ \\
P2 & 1.56 & P1 & 2.40 \\
P3 & 1.13 & P2 & 2.31 \\
P4 & 0.74 & P3 & 2.19 \\
P5 & 0.60 & P4 & 1.77 \\
\hline \multicolumn{4}{c}{ Indeks Vigor } \\
P1 & 0.44 & P2 & $\mathbf{0 . 8 6}$ \\
P3 & 0.39 & P1 & $\mathbf{0 . 8 0}$ \\
P2 & 0.32 & P3 & 0.52 \\
P4 & 0.00 & P4 & 0.00 \\
P5 & 0.00 & P5 & 0.00 \\
\hline \multicolumn{5}{c}{ Potensi Tumbuh Maksimum } \\
P1 & 0.60 & P1 & 0.49 \\
P2 & 0.37 & P2 & 0.45 \\
P3 & 0.24 & P3 & 0.37 \\
P4 & 0.09 & P4 & 0.19 \\
P5 & 0.06 & P5 & 0.18 \\
\hline \multicolumn{5}{c}{ Kecepatan Tumbuh } \\
P1 & $\mathbf{7 . 7 7}$ & P5 & $\mathbf{2 8 . 5 4}$ \\
P5 & $\mathbf{7 . 1 6}$ & P4 & $\mathbf{1 6 . 2 9}$ \\
P4 & $\mathbf{5 . 3 1}$ & P3 & $\mathbf{1 2 . 3 9}$ \\
P2 & $\mathbf{4 . 8 4}$ & P2 & $\mathbf{1 0 . 3 4}$ \\
P3 & $\mathbf{4 . 0 3}$ & P1 & $\mathbf{9 . 3 5}$ \\
\hline
\end{tabular}

dua kelompok lot benih yaitu lot benih dengan nilai vigor daya simpan yang tinggi dan lot benih dengan nilai vigor daya simpan yang rendah. P1 dan P2 merupakan lot benih dengan nilai vigor daya simpan yang tinggi. Sedangkan P3, P4, dan P5 merupakan lot benih dengan nilai vigor daya simpan yang rendah. Berdasarkan hasil pengujian menunjukkan perlu adanya pengkajian lebih lanjut terhadap metode pengusangan secara kimia dan penyimpanan terkontrol dengan menggunakan larutan garam jenuh $\mathrm{Na}_{2} \mathrm{SO}_{4}$ terkait konsistensi hasil yang didapatkan.

\section{KESIMPULAN}

Terdapat kesesuaian penurunan vigor antara benih yang diusangkan dengan metode pengusangan cepat menggunakan uap etanol menggunakan Alat Pengusangan Cepat IPB 77-1 MM dengan benih yang disimpan dalam kondisi penyimpanan terkontrol. Metode pengusangan dan penyimpanan dapat dipergunakan hanya untuk benih dengan vigor tinggi sedangkan untuk vigor yang rendah metode pengusangan dan penyimpanan tidak dapat dipergunakan. Alat Pengusangan Cepat IPB 77-1 MM dapat digunakan untuk melihat perbedaan vigor daya simpan pada kelima lot benih benih jagung pada tolok ukur daya berkecambah, potensi tumbuh maksimum, sedangkan untuk tolok ukur indeks vigor dan 
kecepatan tumbuh belum menunjukkan konsistensi penurunan vigor hasil pengusangan cepat benih secara kimia.

\section{DAFTAR PUSTAKA}

Badriah, R. 2012. Pemanfaatan alat pengusangan cepat (APC) tipe IPB 77-1 MM untuk pendugaan vigor daya simpan benih Jagung (Zea mays L.). [Skripsi]. Institut Pertanian Bogor. Bogor.

[BSN] Badan Standardisasi Nasional. 2003. Benih jagung bersari bebas kelas benih dasar. http://sni.bsn.go.id/product/detail/6703. [19 Juli 2018].

[DitjenTP] Direktorat Jenderal Tanaman Pangan. 2016. Luas panen hasil per hektar dan produksi di Indonesiatahun 2014 tanaman jagung. http://tanamanpangan.pertanian.go. id/assets/front/uploads/document/JAGUNG _2014.pdf. [19 April 2017].

[ISTA] International Seed Testing Association. 2014. International Rules for Seed Testing. ISTA. Bassersdorf, CH-Switzerland.

Mugnisjah, W.Q., A. Setiawan, Suwarto, C. Santiwa. 1994. Panduan Praktikum dan Penelitian Bidang Ilmu dan Teknologi Benih. Raja Grafindo Persada. Jakarta.

Nurfarida, M. 2011. Pengembangan uji cepat vigor benih jagung (Zea mays L.) dengan alat pengukur laju respirasi kosmotektor. [Skripsi]. Institut Pertanian Bogor. Bogor.

Paramita, K.E., T.K. Suharsi, M. Surahman. 2018. Optimasi pengujian daya berkecambah dan faktor yang mempengaruhi viabilitas dan vigor benih kelor (Moringa oleifera Lam.). Bul. Agrohorti. 6(2): 212- 221.

Radha, B.N., B.C. Channakeshava, H. Nagaraj, K.T. Pandurange Gowda, K. Bhanuprakash, R.R Munirajappa. 2013. Effect of seed ageing on protein quality and quantity in maize. Int. J. Bioassays. 3(1): 1708-1713.
Rahmawati, N.E., T.K. Suharsi, M. Surahman. 2016. Pengusangan cepat fisik serta penyimpanan benih Koro Pedang (Canavalia ensiformis (L.) DC.) menggunakan ruang simpan dan kemasan berbeda. Bul. Agrohorti. 4(3): 327-335.

Sadjad, S. 1993. Dari Benih Kepada Benih. PT Grasindo. Jakarta.

Sheidaei, S., H.H.S. Abad, A. Hamidi, G.N. Mohammadi, A. Moghaddam. 2014. Evaluation of soybeen seed quality under long term storage. IJB. 5(3): 214-219.

Suhartanto, M.R. 2013. Teknologi pengolahan dan penyimpanan benih. Dalam Elviana, (ed.). Dasar Ilmu dan Teknologi Benih. IPB Press. Bogor.

Tatipata, A., P. Yudono, A. Purwantoro, Mangoendidjojo. 2004. Kajian aspek fisiologi dan biokimia deteriorasi benih kedelai selama penyimpanan. Jurnal Ilmu Pertanian. 11(2):76-87.

Terryana, T.R. 2013. Pemanfaatan mesin pengusangan cepat (MPC) IPB 77-1 MM untuk penapisan vigor daya simpan benih kedelai (Glycine $\max$ L.). [Tesis]. Institut Pertanian Bogor. Bogor.

Widajati, E., E. Murniati, E.R. Palupi, Suharsi T.K, M.R. Suhartanto, A. Qadir. 2012. Dasar Ilmu dan Teknologi Benih. IPB Press. Bogor.

Zanzibar, M., A.A. Pramono. 2009. Penentuan vigor kekuatan tumbuh dan vigor daya simpan relatif benih merbau, akor dan mindi. Jurnal Penelitian Hutan Tanaman. 6(3):145-155. 